\title{
The Language in Language and Thinking
}

\author{
Vivian Cook \\ Newcastle University \\ Vivian.Cook@ncl.ac.uk
}

\begin{abstract}
The relationship of language and thinking is starting to receive considerable attention in the field of SLA research under the name of Bilingual Cognition. This paper argues that it needs to be underpinned by a proper foundation in the language side of the relationship: it is dangerous to take language for granted. First it argues for researchers to clearly spell out what they mean by language, whether as the general property of human beings, in an abstract sense, as an external reality, as mental knowledge, as social community or as action, each of which has different implications for the relationship of language and cognition. Then it argues for the Language Commitment to an adequate theory and description of language as a basis for research, claiming that current emphasis is too much on isolate semantic categories rather than syntactic categories and on word-referent mapping rather than the full complexity of lexical meaning.
\end{abstract}

Keywords: Language and thinking, linguistic relativity, SLA research, Linguistic Commitment, thinking for language

\section{Resumen}

La relación del lenguaje y el pensamiento está comenzando a recibir una atención considerable en el campo de la investigación de segundas lenguas bajo el nombre de Cognición Bilingüe. Este artículo argumenta que debe estar respaldado por una base adecuada en lo que respecta a la lengua en esta relación: es peligroso dar por sentada la lengua. Primero, defiende que los investigadores expliquen claramente qué entienden por lengua, ya sea como propiedad general de los seres humanos, en un sentido 
abstracto, como realidad externa, como conocimiento mental, como comunidad social o como acción, cada uno de los cuales tiene diferentes implicaciones para la relación de la lengua y la cognición. Posteriormente, defiende el Compromiso de la Lengua con una teoría adecuada y una descripción del lenguaje como base para la investigación, alegando que el énfasis actual está demasiado centrado en las categorías semánticas aisladas en lugar de en las categorías sintácticas y en el mapeo de palabra-referencia en lugar de en la complejidad total del significado léxico.

Palabras clave: lengua y pensamiento, relativismo lingüístico, investigación en ASL, Compromiso Lingüístico, pensar para la lengua

\section{Introduction}

The 1990s heralded a renaissance of research into the relationship between language and thinking, alias linguistic relativity, basically establishing that speakers of different first languages behave differently on a variety of cognitive tasks such as spatial orientation (Levinson 1996), classification of objects (Lucy 1992) and perception of colours (Davidoff, Davies \& Roberson 1999). Recently this has started to affect second language acquisition (SLA) research through a spate of books (De Groot 2010; Han \& Cadierno 2010; Pavlenko 2011; Cook \& Bassetti 2011), coming to be called the field of bilingual cognition. The current paper is an attempt to look at some of the underlying issues of the relationship between language and thinking in the context of second language acquisition. A survey of the bilingual cognition research itself is available in Bassetti and Cook (2011).

The discussion of the relationship between language and thinking inevitably hinges on what the words language and thinking are taken to mean. There are doubtless as many linguistic models of language as there are psychological theories of thinking. Investigating the relationship between language and thinking therefore means being explicit about the nature of both language and thinking and being aware of the alternative versions of both. Any language and thinking research in effect tests whether an aspect of cognition relative to a particular psychological theory correlates with an aspect of language relative to a particular linguistic theory.

But there are obvious dangers in such marriages of convenience. The two partners need enough in common to have a relationship: the theory and description of cognition and the theory and description of language have to be compatible; the research has to choose relevant cross-disciplinary aspects of language and cognition out of the many possibilities that present themselves. Yet they also need to be sufficiently different for each to make their own contribution; psychological theories that deny a distinctive 
role to language have little relevance as they deny the relationship in advance. Equally linguistic theories that put impermeable barriers between language and cognition have little to contribute.

Linguists and psychologists are both primarily responsible for their own side of the garden fence and may deny any duty to look at it from their neighbours' side. Both linguists' views of thinking and psychologists' views of language are undoubtedly regarded as naïve by their counterparts in the other discipline. Yet research into language and cognition depends on balancing both. To be credible, the language and thinking debate has to be couched in terms that are sound for both sides. Evans (2011: 71) talks of the Cognitive Commitment to use 'a characterization of language that accords with what is known about the mind and brain from other disciplines'. This paper argues the parallel need to pin down the language side of the relationship, called the Language Commitment in Cook (2011). Though this is central to the structurecentred approach to language and thinking (Lucy 1997), a working concept of language is still necessary whichever approach is adopted. The paper tries to make two simple points: language is many things to many people; research connecting language to thinking should use an adequate analysis of language.

\section{Meanings of language}

A starting point is the English word language, virtually taken for granted in most discussion. Yet language is not a word with a single unambiguous interpretation: it means what a particular theory says it means. Nor are the meanings of the English word language necessarily found in other languages: compare say the French distinction between langue, langage and parole (de Saussure 1916/1976). Similar problems occur with the English word cognition, which has no equivalent in Polish (Wierzbicka 2011). A fatal trap in language or cognition studies is to assume that English can be the neutral language for describing either, prevalent for example in Whorf's habit of translating Hopi notions into English (Whorf, 1941a/1956).

Cook $(2007 ; 2010)$ has distinguished different meanings of language in English, seen in the table below, which will be used to organise the discussion here. These are working definitions rather than watertight boxes and doubtless overlap and contradict each other in various ways; they are discussed more fully in Cook (2010). 
Table 1. Six meanings of language (based on Cook, 2007; 2010)

\begin{tabular}{lll}
\hline Lang $_{1}$ & a human representation system & 'human language' \\
Lang $_{2}$ & an abstract external entity & 'the English language' \\
Lang $_{3}$ & a set of actual or potential sentences & 'the language of Shakespeare' \\
Lang $_{4}$ & the possession of a community & 'the language of English people' \\
Lang $_{5}$ & $\begin{array}{l}\text { the knowledge in the mind of an } \\
\text { individual }\end{array}$ & 'I know English' \\
Lang $_{6}$ & a form of action & 'language is doing' \\
\hline
\end{tabular}

- The Lang $_{1}$ sense of language as a representation system treats it as a possession of human beings: 'a species-unique format for cognitive representation' (Tomasello 2003: 13). Lang language is an uncountable noun; you have Lang language or you don't but you don't have $a$ Lang $_{1}$ language. Here the language/ thinking relationship is at its most general: does human language itself have a connection to human thinking rather than any particular language? Lucy (1997: 292) describes this as a semiotic level at which 'speaking any natural language at all may influence thinking'. In this sense, human beings themselves are incapable of examining the links between their language and their thinking: only a non-human intelligence not bound by human language and thinking might be able to detect them.

In the multi-competence perspective, most of the human race are seen as possessing languages, not language; all human beings have the initial potential to acquire more than one language (Cook 2009). It cannot be assumed that a typical human being knows only a single language with a single grammar, a single mental lexicon, and so forth. The question is not so much how knowing a single language relates to our thinking as how knowing two or more languages relates to thinking. Perhaps the general links of Lang to thinking occur regardless of how many languages the person knows; perhaps, however, the second language (L2) user connects language to thinking in ways that monolinguals are not capable of.

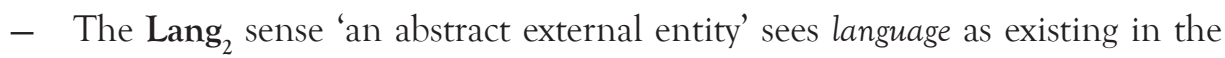
world of abstractions; it is described in rulebooks such as the dictionary and the grammar. So the English language is codified in grammars such as the Comprehensive Grammar of the English Language (Quirk et al 1972) and dictionaries such as the Oxford English Dictionary (OED 1997); seven governments agreed in 1990 on a protocol for reforming the spelling of 
Portuguese. Anything that has ever occurred in the language anywhere is part of Lang: every recorded word since $1150 \mathrm{AD}$ is in principle present in the pages of the OED.

Lang $_{2}$ is dangerously confusable with the individual's knowledge of language, described below as Lang ${ }_{5}$. For Lang 2 is not the same as individual knowledge in scope - who could actually know the 430 meanings of the word set included in the OED or the contents of all 1779 pages of the Comprehensive Grammar? Nor does it correspond to any individual's actual usage; at best this will comprise a small subset of the words and grammatical rules in the Lang language. In addition, it sweeps dialect speakers under the carpet in favour of a single standard, usually the variety spoken by a status group from one area or one class. Nor does the form of the grammarian's description have a necessary connection to the knowledge stored in the brain; it is highly unlikely that the rules of the grammar-book correspond directly to the systems and processes in individuals' minds, let alone to the way they are stored in their brains.

Lang $_{2}$ is language as a countable noun; there is the English language, the French language ... up to the 6,909 living languages in Ethnologue (Lewis 2009). Hence the question can be asked whether users of Lang 2 A think differently from users of Lang 2 B, just as it might be asked whether people in countries with Common Law legal systems behave differently from those in countries with the Napoleonic Code. This is a matter of correspondence between an idealised language object and idealised thinking, typical of early suggestions from Whorf about Hopi and Algonkian languages (Whorf 1941a/1956).

The prime source of insights for one type of Lang 2 analysis is the mind of the investigator, supplemented by observations of people, texts or experiments, as in the great English grammars of Jespersen (1933) and Zandvoort (1957), rather than large corpora of texts. An outstanding modern exponent is Talmy, whose analyses of language deal with an ideal object and usually with more than one language; the evidence in Talmy (2005) consists of thought experiments describing boards lying across streams and personal communications about Dutch and Makah rather than descriptive grammars or sentences collected in a corpus. Such analysis depends on the brilliance of its instigator, as in Talmy's (1985) seminal observation of the distinction between verb-framed languages like Spanish that express path and motion separately entra caminando 'he enters walking' and satellite-framed languages like English that express it though particles he walked in. This has become a pillar in the language/ thinking debate, as we see from many of the papers in Pavlenko (2011) and Han and Cadierno (2010). It is clearly an insight about a Lang abstract entity. 
Lang $_{2}$ entities have always been seen as single languages rather than in-between languages like pidgins, since the eighteenth century often identified with a nation-state (Anderson 1983). Corpora and grammars are now starting to emerge for varieties of English such as English as Lingua Franca (ELF) that do not have native speakers (Seidlhofer 2004). However, these are descriptions of native-speaker-less languages, not authoritative statements of the Lang ${ }_{2}$ of a multilingual nation or group, and have indeed been attacked for undermining the 'standards' of such national communities. The Lang 2 sense is equally remote from the L2 user; an individual L2 user no more knows a Lang $_{2}$ in either language than a monolingual.

- Lang $_{3}$ is language as 'a set of actual or potential sentences': 'the totality of utterances that can be made in a speech-community' (Bloomfield 1926/1957: 26): a language is a corpus of sentences that have been spoken or written. This approximates to the sense of language in usage-based connectionist and emergentist studies in psychology and Conversation Analysis. This can be opposed to the Chomskyan notion that the goal of a grammar is to describe all the sentences that could be spoken or written - the creative aspect of language use (Chomsky 1972: 100) - i.e. the potential sentences rather than the actual sentences that happen to have been spoken. Lang $_{3}$ descriptive grammars such as Biber et al (1999) reflect the properties of actual corpora; the COBUILD dictionary (1995) reports meanings from actual usage rather than the complete definitions found in the OED. The question of whether the set of sentences constituting language $\mathrm{A}$ goes with different cognition from the set constituting language $\mathrm{B}$ is, however, virtually unanswerable as language is being treated as a objective external object, not as an internal mental reality, and so the possibility of thinking as such does not arise without involving other senses.

- The Lang $_{4}$ sense is language as 'the possession of a community': 'The mental individuality of a people and the shape of its language are so intimately fused with one another, that if one were given, the other would have to be completely derivable from it' (Humboldt 1836/1999: 46). Lang $_{4}$ is shared among a group of speakers such as 'the English-speaking world' or 'native speakers of Chinese'. A language community is often equated with a nation people born in Japan tend to speak Japanese. Nevertheless, Sapir (1921: 179) insists 'It is impossible to show that the form of a language has the slightest connection with national temperament'. A language community can also be a virtual community unconstrained by political borders (Anderson 1983): Kurdish is spoken in Iraq, Turkey and Iran despite the lack of a country of 
Kurdistan. A community may also be multilingual, using several languages for different functions in everyday life. In India for example everyone has to know Hindi and English, plus the local state language if the local state language is neither Hindi nor English, known as the 'Three Language Formula' $3 \pm 1$ system (Laitin 2000).

The question for thinking and language research is then whether the social interaction of Lang ${ }_{4}$ and the sense of identity it promotes in its speakers link in some way to their thinking: 'languages reflect cultural preoccupations and ecological interests that are a direct and important part of the adaptive character of language and culture' (Evans \& Levinson 2009: 436). It might be comparatively easy to demonstrate this in terms of social interaction. The terms of respect in Japanese or the alternative pronouns for social status in Thai undoubtedly go with particular social values. Language is bound to mirror the way the society functions. But does language lead or follow? The disappearance of the Old English word sweostersunu ('sister's son', i.e. nephew) attests to the decreased importance of the uncle/nephew bond but is hardly responsible for it.

Extending Lang to L2 users raises a long contested issue of how community goes with language. Does the individual L2 user effectively belong to two communities or do they belong to a different community specifically of L2 users, as in the case of ELF? On the one hand Mackey (1972: 554) claims 'An individual's use of two languages supposes the existence of two different language communities; it does not suppose the existence of a bilingual community'; on the other Brutt-Griffler (2002) proposes 'the multi-competence of the community' and Canagarajah (2007: 930) insists 'Linguistic diversity is at the heart of multilingual communities.' The $\mathrm{Lang}_{4}$ link between language and thinking needs to take multilingual communities into account, not just those which employ a single language.

- The Lang $_{5}$ sense of language refers to an individual's mental knowledge: 'a language is a state of the faculty of language, an Ilanguage, in technical usage' (Chomsky 2005: 2). The classic competence/performance distinction (Chomsky 1965; 1995) in part distinguishes Lang $_{5}$ mental knowledge from Lang $_{3}$ sets of sentences in so far as performance refers to 'the actual use of language in concrete situations'.

This sense of language is perhaps the one most used in language/thinking research, hardly surprisingly since it involves a concept of mind: the crucial connection is between individual mental knowledge of language and 
individuals' thinking, as seen in say 'adult L2 acquisition is a process of establishing form-meaning connections' (Ekiert 2010: 125). In methodological terms, a description of Lang $_{5}$ individual knowledge is neither the same as the general rules of the language described in Lang $_{2}$ nor as the pattern regularities in the individual's Lang $_{3}$. The valid relationship is that between the individual's linguistic competence and the individual's thinking.

There is often therefore a tension between language as an abstract codified system, as a community possession and as knowledge in an individual mind. Many see the community Lang $_{4}$ and the individual Lang 5 meanings as two sides of the same coin: 'although languages are thus the work of nations ... they still remain the self-creations of individuals' (Humboldt 1836/1999: 44). The slogan of interactionist psychology was $\mathrm{B}=\mathrm{f}(\mathrm{P}, \mathrm{E})$ (Lewin 1936; Cook 1981) - behaviour is a function of Person and Environment, translatable into 'language is both internal Lang 5 and external Lang'. Yet whole theories of linguistics have based themselves exclusively on the internal Lang ${ }_{5}$ meaning, just as whole theories of psychology have based themselves on the external Lang $_{3}$ sense, whether behaviourism, connectionism or emergentism.

The importance for the language-cognition debate is the relationship between the two language systems in the same mind. Cook (2003) talked of an integration continuum between the poles of total separation and total integration of the two languages, related to Weinreich (1953)'s distinction between coordinate and compound bilingualism. Neither pole is completely achievable: total separation is impossible since the two languages coexist in the same mind; total integration is impossible as the speaker would be unable to control which language they were speaking. The point on the continuum at a given moment varies according to the aspect of language involved, say phonology, syntax or semantics, and the choice of bilingual or monolingual mode (Grosjean, 1998). So, establishing the Lang ${ }_{5}$ of an individual may be trickier when the more complex language system of the L2 user is involved. While it would be attractive to take the well-known Chomskyan metaphor that we need to study the pure water of monolingualism rather than sample the polluted waters of the River Charles of bilingualism, this does not work if bilingualism is everyone's potential state and if bilingual minds are more common and more typical than monolingual ones.

- Lang $_{6}$ is 'language as action', as expressed say in Schegloff et al (2002: 5), 'People use language and concomitant forms of conduct to do things, not only to transmit information', long part of the British school of linguistics (Malinowski 1923; Halliday 1978) and an important constituent of Vygotskyan 
theory in that language development consists of the child internalising external social action (Vygotsky 1934/62).

Do the things that people do with language differ from one language to another? A major assumption of 1970s communicative language teaching was that people had to be taught to complain or to argue rather than taught the vocabulary and grammar for complaining or arguing. This survives in the Common European Framework (2001) for language teaching devised by the Council of Europe, which measures language proficiency through 'cando' statements such as 'I can order a meal' and 'I can recognise familiar names'. One interpretation of Lang ${ }_{6}$ for language/thinking research would be to see how different ways of speaking linked with different ways of acting, corresponding to the behaviour-centred approach (Lucy 1997).

The relevance of L2 users for the language/thinking debate again concerns whether we think monolingual action or L2 user action is the norm. Businessmen like the Arab and Danish L2 users of English described in Firth (2009) are not using English in the same way as their monolingual colleagues; they carrying out L2 acts that do not necessarily have monolingual counterparts and which they might well be incapable of doing in their first language. Similarly, codeswitching is a resource available to L2 users that enables them to make subtle points about social status and topic by changing language. Before linking L2 users' language to their actions and their thinking, we need to know what is distinctive about them that is lacking from those of monolinguals.

To sum up, the links between language and thinking vary according to the sense of language being used. A claim about abstract standard Lang 2 is not the same as one about social community Lang $_{4}$ or individual mental Lang ${ }_{5}$, particularly if L2 users and their communities are taken into account. For example, Sapir says 'we see and hear and otherwise experience very largely as we do because the language habits of our community predispose certain choices of interpretation' (Sapir, cited in Whorf (1941a/1956: 134)). Perhaps language/thinking research needs to take all of these aspects of language into account; perhaps it needs to concentrate on one or two. But it cannot duck the responsibility to specify exactly which meaning or meanings of language it is utilizing and whether one language is involved or more than one.

Take the idea of grammar. The grammar of the $\mathrm{Lang}_{2}$ grammar book is not actually known to individual speakers. Firstly, it is a generalization, based either on large numbers of sentences and people or on the insights of gifted 
grammarians; secondly, it includes all the rules of 'the language' rather than the subset of the rules any individual might use; thirdly, it is unlikely to be in a

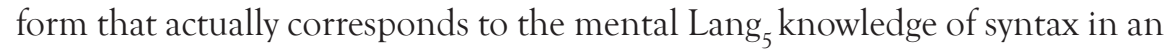
individual's mind; fourthly, being based on monolinguals, it does not include complex language systems known and used by L2 users. Many examples over the years have shown how out of step these different 'grammar's can be; the Lang $_{2}$ book grammar of English will insist on the object case in non-subject positions yet a recent UK Foreign Secretary said people like you and I; such crucial Chomskyan test-cases of syntax as the differences between eager/easy to please and the subjacency principle in *Who is that she met worrying? turn out not to apply to many of the native English-speaking population: the standard institutional Lang 2 grammar reflects the Lang knowledge of individual speakers imperfectly. Any syntactic property that is tested for fit against one person's thinking needs to come out of the Lang ${ }_{5}$ mental grammar of that

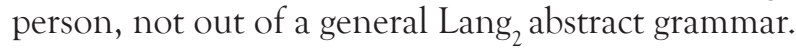

\section{Aspects of language in relationship to thinking}

The word language has many facets, reflected in the spectrum of linguistic disciplines from phonology to syntax to sociolinguistics, and a dozen more. None of these specialities boast a single uncontested theory or an agreed set of descriptive terms and categories. Phonology encompasses theories as diverse as optimality theory and lexical phonology, some relying on terms such as phoneme, distinctive feature or constraint ranking, some rejecting them out of hand. The relationship of language to thinking depends not only upon the meaning of language employed but also on the specific aspect of language involved and the methods of analyzing it. The links between optimality phonology and thinking are certainly likely to be different from those between componential semantics and thinking. Out of the thousands of possible aspects of language, one or two are bound to favour or deny a link to some equally arbitrary aspect of thinking by chance, unless the choice is severely constrained by the theory or area of language. Research into language and thinking needs careful specification of the aspects of language that are used.

\subsection{Syntactic categories and grammar}

According to Whorf, the categories of noun and verb make Standard Average European thinking divide the world into things and actions, unlike the thinking of Hopi speakers; 'English and similar tongues lead us to think of the universe as a collection of rather distinct objects and events corresponding to words... as goes 
our segmentation of the face of nature, so goes our Physics of the Cosmos' (Whorf, 1941b/1956: 241). His nouns and verbs are defined in almost the traditional terms of school grammar, represented, say, by Cobbett (1819: 12-15), 'Nouns are the names of persons and things. .. Verbs express all the different actions and movements of all creatures and of all things, whether alive or dead'.

Linguists used to inveigh against such semantic definitions of parts of speech on the grounds of their woolliness (the noun fire is hardly an object, the verb seem hardly an action), and their overlap (request is both a noun and a verb, up can be a preposition up the hill, a noun ups and downs and a verb Up the grant!). No two people would agree on whether many words were nouns or verbs by these subjective definitions; at best there is a statistical tendency that a noun will refer to an object, a verb to an action (Lyons 1966). Instead linguists have preferred to define syntactic categories in terms of formal structural properties; Fries (1952) defines words that can be inflected for number and can be preceded by a determiner as Word Class 1; i.e. nouns are defined structurally rather than notionally. Other linguists have treated noun and verb as primitive terms - 'certain fixed categories (Noun, Verb, etc.) can be found in the syntactic representation of the sentences of any language' (Chomsky 1965: 28); these are then substantive universals - 'items of a particular kind in any language must be drawn from a fixed class of items' (Chomsky 1965: 28) - a built-in aspect of the human mind. Even Sapir (1921: 96) has a universal leaning: 'There must be something to talk about and something must be said about this subject of discourse... No language wholly fails to distinguish noun and verb, though in particular cases the nature of the distinction may be an elusive one'. Oddly enough many of those who reject the Chomskyan idea of innate universals of language are quite happy to use nouns and verbs (and indeed word) as self-evident universal categories. But even Chomsky's definition refers to syntactic properties; it is an empirical question whether there are two groups of word-classes that can be isolated in all languages on the grounds of syntactic properties (Robins 1952).

The view that nouns and verbs relate to things and actions respectively derives more from the semantics-based school tradition of grammar-teaching than from the linguistics tradition, in which the connection between parts of speech, i.e. syntactic categories, and thinking starts from their syntactic nature; as Sapir puts it, 'A part of speech outside of the limitations of syntactic form is but a will o' the wisp' (Sapir 1921: 96). Linking syntactic categories to thinking would involve first demonstrating that categories such as noun and verb are not universal, as implied say in Chomskyan theory but refuted by their absence in Straits Salish (Jelinek (1995) cited in Evans \& Levinson (2009)) or by Nootka studied by Sapir himself (Robins 1952), and secondly correlating thinking with syntactically defined categories: what does syntactic rather 
than semantic nouniness correspond to in thinking? Researching the relationship of a syntactic category to thinking is not the same as investigating the effects of a semantic feature of a group of nouns. When Evans \& Levinson (2009: 000) say 'each word class we add to the purported universal inventory would then need its own accompanying set of syntactic constraints', they are putting the cart before the horse: a word class is precisely the label for a set of words that have the same syntactic constraints, not a concept in search of its syntactic characteristics.

Much language/thinking research with nouns has concentrated on the article system, alias determiners. In English the written and spoken forms of the articles

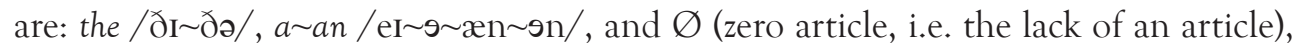
which precede the noun. Put simply, the main English article system is a complex intertwining of:

- definite/indefinite the man/a man (singular), $\varnothing$ the men/men (plural),

- countable/uncountable a man/Ø man,

- singular/plural a man/the man/the men/Ø men

- first/second mention a man came in/the man spoke.

Some uncountables can be quantified with classifier-like phrases, a cup of tea or $a$ pile of sugar. Subtle everyday uses abound, say the function/place difference between he went to hospital and he went to the hospital, or the $\varnothing$ article before certain professions; he's professor of English at UCL. And phonology also enters in through the meaning difference between stressed and unstressed forms; John is the /ða/ man to watch versus John is the /OI:/ man to watch. A more extensive discussion of English articles in a language and cognition context can be found in Ekiert (2010).

The English article system is notoriously hard for speakers of Chinese and Japanese to acquire, examples include mistakes such as a research and an evidence familiar to all university teachers. But it is not just mass versus count nouns that gives students problems nor the absence of articles from their first languages so much as the sheer complexity of the English article system, attested by the vast literature on the L2 acquisition of English articles, say Butler (2002), Master (1994) and Thomas (1989). Evans (2011) makes a three-way distinction between $a$ introducing 'a referent which the hearer is held to be unable to readily identify', $a$ designating 'a unitary instantiation of the referent' and the introducing 'a referent which the hearer is held to be able to readily identify'. This takes in the discourse context but does not mention the zero article, equally part of the article system, i.e. the plural form of $a$ with unidentifiable nouns is zero a man came in/ $\varnothing$ men came in. And it does not include the other uses of $a$. 
It is important then that, in any language and cognition research, the linguistic elements are properly described. In a typical example Imai and Gentner (1997) looked at how speakers of classifier languages like Japanese classify objects differently from speakers of non-classifier languages like English. The crucial point is 'the grammatical distinction between count nouns and mass nouns', i.e. countability, which exists in English but not in Japanese. This distinction is signalled by the presence of $a$ before book, a book, and its absence before sand, " $a$ sand, and the plural form books but not *sands. Syntactically this analysis reduces a complex syntactic meaning-related formal system to an either/or semantic choice. The Linguistic Commitment requires full syntactic analyses for the determiner systems of both languages, as is for instance carried out in Lucy (1992). A similar reduction of complex syntactic matters to an either/or choice is seen in Talmy's satellite/verb-framed distinction, which appears to be a matter of frequency of occurrence within a language rather than an either/or distinction across languages (Croft,2010).

So the analysis in language and thinking research usually establishes two classes of nouns, count and mass, on semantic grounds rather than as syntactic features of nouns that vary continuously (Bollinger 1969). It is always possible to create countable forms for mass nouns with specialised meanings, the sands of time, the waters of the Nile, or uncountable forms for count nouns there is too much book in school. Most language and cognition research is based on the meanings associated with nouns rather than on their formal syntactic properties. Where Imai \& Gentner (1997) claim to be talking about 'count/mass syntax', they are actually talking about count/mass semantics: the syntax is far more complex - whichever syntactic model might be used.

Nor are nouns the only syntactic category to be treated semantically rather than syntactically in this research. Coventry et al (2011) for example explored how English/ Spanish bilinguals express spatial relationships through prepositions such as in glossed as 'containment' and on glossed as 'having support'. The linguists Leech \& Svartvik (1975: 83-85) talk, not of a pair of prepositions in/on, but of 'in-type' prepositions that include into, in, out of, through involving an area or volume, and 'on-type' prepositions such as onto, on, off, across, along involving a line or a surface; volume and surface contrast in He was living on a desert island and He was born in Cuba. As with nouns, the linguist sees a complex network of meanings, usually finding it difficult to make hard and fast divisions between pairs such as in and on. Testing out the meanings of pairs of prepositions against thinking reduces prepositions to isolated atoms of meaning rather than complex molecules; prepositions contrast with many other prepositions not just with one, in a plane, on a plane, inside a plane, with a plane, inside a plane, by plane, and so on, each with a meaning that contrasts with the others to a greater or lesser extent. Most uses of in and on are in fact temporal, in the afternoon and on Tuesday, not 
spatial. Other uses are directional, arrive in and on your left. The containment/support distinction is thus one small facet of the use of in and on. Our knowledge of in and on is many-facetted; even beginners in the language need to know multiple meanings for in and on. Do 'container in' and 'surface on' stand out sufficiently from this web of meanings to be testable cross-linguistically? Levinson (2003: 38) feels 'in general it is hard to find any pair of spatial descriptors with the same denotation across languages'.

Primarily to linguists, preposition is a structural category, like noun, defined by its appearance before noun phrases - in a moment, on the train; 'Typically, prepositions function as the first constituent of a prepositional phrase' (Greenbaum 1996: 159). Comparing two languages is not just taking in certain core meanings of the prepositions but also looking at how they behave syntactically, at the extreme with the postpositions of Japanese that occur after the noun phrase nihon ni (Japan in) rather than before in Japan. Prepositions have a complex set of syntactic behaviours in English, going with particular verbs come on/come in and adjectives dependent on/ disappointed in. Prepositions are not independent units like content words but have a syntactic function like articles; they are partly like closed-class function words, partly like open-class content words. Unless cross-linguistic comparison takes such basic information on board, research results may be skewed by the other syntactic and semantic features of preposition oppositions like in and on across languages. Again language and cognition research tends to deal with them as semantic units rather than syntactic categories.

The major syntactic differences between languages have, oddly enough, seldom featured in the language/thinking debate, for example the contrast between configurational languages which have phrase structure and non-configurational languages which do not (Hale 1983) and the preposition/postposition word order difference seen in English and Japanese. Whorf made the interesting claim that 'Hopi can and does have verbs without subjects, a fact which may give that tongue potentialities, probably never to be developed, as a logical system for understanding some aspects of the universe' (Whorf, 1941b/1956: 243). Since Chomsky (1981), this has been known as the prodrop or null subject parameter; $97 \%$ of languages allegedly have verbs without surface Subjects, the well-known exceptions being English, German and modern written French. Yet no-one appears to have correlated such a well-attested syntactic difference with differences in thinking. One exception where a syntactic difference per se was indeed correlated with a thinking difference was Bloom (1981)'s controversial attempt to link the presence of if-clauses in English such as If he had not gone to the forum that day, Caesar would have lived longer with the ability to reason counterfactually. And indeed, crucially for the Linguistic Commitment, we need to establish an overall syntactic theory within which the languages can be compared on 
an equal footing (Stringer 2010), rather than using English as an unacknowledged universal system into which other languages can be converted (Wierzbicka, 2011).

The relationship between language and thinking has then often been conceived in terms of semantics, not of syntax, of the meanings of words and sentences, not of their form, as if syntax were an unimportant appendix to language. Syntax is seldom treated in its own right as having syntactic form and meaning but seen as a vehicle conveying a basic set of semantic meanings; gender for instance is not seen as syntactic agreement between elements in the sentence but as semantic and arbitrary meanings attached to nouns. Yet the way that we think could be as influenced by the way we construct our sentences as by what we mean by our words, as the writing-direction research of Tversky et al. (1991) suggests. It is one thing to deduce a relationship between syntax and thinking based on a formal feature of syntax, whether the effects of SVO, the syntactic categories of noun and verb or the presence or absence of articles; it is another to deduce a relationship from a semantic idea incorporated in a complex web of syntactic devices, such as gender and mass/count. What is being asked for is then in the spirit of Brown (1986: 482): 'Relativity is the view that the cognitive processes of a human being - perception, memory, inference, deduction - vary with the structural characteristics - lexicon, morphology, syntax - of the language he speaks'. This is not the same as saying that semantic notions expressed in syntax correlate with concepts in cognition - of course they do or language would be impossible.

\subsection{Lexical items and sets}

The bridge between language and thinking has usually been perceived as the lexicon. Famously Whorf (1940/1956: 216) based arguments for linguistic relativity on the many words for snow in Inuit, the scarcity of 'snow' words in English and the reduction of 'cold', 'ice' and 'snow' to one word in Aztec. Yet Sapir (1921: 181) pointed out 'the linguistic student should never make the mistake of identifying a language with a dictionary'.

The area of colour research investigates how the set of colour terms in the lexicon of a language relates to 'objective' measures of colour such as hue and saturation, as seen in Athanasopoulos (2011). As with grammar, there are a range of linguistic theories and tools for handling lexis and its importance varies according to one's theory. For instance, while Chomsky's theory is often seen as syntactic, its instantiation in the Minimalist Program treats syntactic structure as a projection from the properties of lexical items, which are then Merged (Chomsky 1995).

Overall, however, there is a major slippage between the way that many psychologists see vocabulary and that adopted by most linguists. One preliminary 
difference is already seen in the term lexical item used in the heading. The category of word prevalent in psychology is extremely hard to define except in the writingbased sense of letters surrounded by spaces; what is a word in a language like Illujuaraalummuulaursimannginamalittauq 'But also, because I never went to the really big house'? (Dorais 1988: 8, cited in Genesee 2003) The unit preferred by linguists is more often lexical item or lexical entry, which may well be more than one word look up, say, or in front of, or lemma in which the various alternate forms of the word are reduced to one; a lexical entry contains far more information than a word's reference,

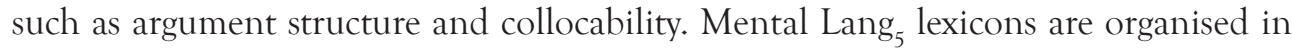
lexical items or entries, not in the words typically found in Lang $_{2}$ dictionaries.

Psychologists by and large regard words as having single core meanings: dog means】, not 'to follow someone closely' or 'a complete flop': one word, one meaning. Levinson (2003: 35) sums this up as the assumption that 'corresponding to a lexical item is a single holistic concept'. Red and blue are taken to refer to particular colours/hues/ saturation on some visual scale or field rather than say to the Labour and Conservative parties, snooker balls or York City Football Club. Evans (2011: 75) for instance distinguishes red ink from red squirrel. This tells us rather little about the wider set of colour terms that red belongs to: in the case of squirrels, the opposition is between red and grey, in ink probably between red, blue, black and green, in roulette between red and black, in traffic lights between red, green and amber, and so on. A word has many meanings in different contexts and relates to the meanings of many other words.

More crucially treating red as a unique visual perception only covers its denotative reference to physical colour rather than its many other uses; it assumes that there is a core aspect of the physical world denoted by the colour term however much this may vary cross-linguistically. Defining the language component of language and thinking is taken to mean enumerating which physical shade on the colour or hue scales etc. the words actually refer to before relating them to different thinking. The central belief is that the purpose of words is refer to things and actions; hence the emphasis in psychologists' research is on content nouns with clear (and usually drawable or at least visible) physical reference, as opposed to structure words like to with syntactic meaning or words with abstract meanings like nation. Imai and Gentner (1997) for example frequently refer to 'names' and 'nouns' as if they were the same - 'substance names and object names', 'children initially learn object names rather than names for relations of properties', 'extending their names on the basis of shape'; discussions of colours frequently talk of 'colour naming' (Regier \& Kay 2009); Malt and Ameel (2010: 175) talk of naming patterns as 'patterns of application of words to objects', Pavlenko (2010: 200) of 'word-to-referent mapping'. To most linguists the word-object link is only one of the many aspects of meaning that go with a word; there is no simple bond between an object in the world and the noun that refers to it: most nouns are 
not names; most nouns have multiple meanings; most meanings do not have clear denotations in the physical word; most meanings relate to other meanings rather than being independent - the basic structuralist claim summarised as 'lexical concepts are defined relative to other items in the lexicon' (Stringer 2010: 102). Indeed in English actual names have their own distinctive grammar with no determiners London apart from rare exceptions like The Hague and their own spelling conventions such as Cooke, Hogg and Smythe.

To linguists, not only do words with unambiguous visual referents form a small subset of the lexicon but also reference is only one aspect of meaning. Take the word blue. One aspect of blue is indeed the peculiar physical shade it refers to. But blue exists in a network of other information. For an English person, its five most common associations are sky, black, green, red, white, sea, colour, yellow, eyes, aristocracy (Edinburgh Word Association Thesaurus 2011). While this confirms a relationship with other colours on the physical scale, it also relates blue to the superordinate level colour in Roschian terms (Rosch, 1977) and to adjective-noun collocations, blue sky/sea/eyes/ blood, the syntagmatic level of association (Deese 1966). Blue is not only an adjective but also a noun, as in Klein blue or Oxford Blue, or, in the plural, a kind of music the blues or the nick-name of Birmingham City and Chelsea football teams. Meanings can be deconstructed into features - blue has the feature [+colour] etc; looked at in networks (Cruse 1986) - blue is the opposite of red in political talk; studied in collocations - blue joke, blue funk, turn blue, black and blue; and counted - blue is $7987^{\text {th }}$ in frequency on the British National Corpus, red $11605^{\text {th }}$.

Doubtless the counter-argument is that blue has a central meaning from which all the others derive: see how people relate this meaning to thinking and that's all that needs to be done. But some linguists precisely deny that words have central meanings: polysemy is the norm. Many of the everyday meanings of blue do not relate to its supposedly core referential meaning; why should a joke be blue (it's yellow in Chinese)? An intellectual woman a blue stocking? Rather the word blue has multiple meanings and connections, of which its denotative link to a quality in the physical world forms a small part. Relating referential meanings of limited sets like colour words to thinking takes in one small aspect of the multitude of possible relationships between language and thinking. It is not that it is unusual or untypical of words to have such a range of senses: cognitive blends are the norm (Fauconnier, 2003). Perhaps only the simulated situations psychological model encompasses the many aspects of a single word: 'perceptual symbols are multimodal, originating in all modes of perceived experience, and they are distributed widely throughout the modality-specific areas of the brain' (Barsalou 1999: 583) The overall point once again is that any attempt to relate words to cognition needs to be grounded on a rich model of words, not only on single denotative meanings. 


\section{Conclusion}

The intention here was to point out that, despite much exciting and novel work into language and thinking, we are getting nowhere until we have spelled out what language means in the context of the particular piece of research. This is not to say that one interpretation of language or one descriptive view of syntax should be preferred; many alternative avenues can be explored. But it is dangerous to take language for granted; lack of explicitness in the discussion often means it falls back by default on folklore and common-sense rather than the scientific study of language practiced in the twenty-first century.

\section{References}

Anderson, B. (1983) Imagined communities. New York: Verso.

Athanasopoulos, P. (2011). Colour and bilingual cognition. In Cook, V. J. \& Bassetti, B. (eds.) (2011) Language and bilingual cognition. (pp. 241-262) New York, NY: Psychology Press.

Barsalou, L.W. (1999) Perceptual symbol systems. Behavioral and Brain Sciences, 22 (4), 577-660.

Bassetti, B. \& Cook. V. J. (2011). Relating language and cognition: the second language user. In Cook, V. J. \& Bassetti, B. (eds.) (2011) Language and bilingual cognition. (pp. 143-190) New York, NY: Psychology Press.

Biber, D., Finegan, E., Johansson, S., Conrad, S. \& Leech, G. (1999). Longman grammar of spoken and written English. Harlow: Longman.

Bloom, A. H. (1981) The linguistic shaping of thought: a study in the impact of language on thinking in China and the West. Hillsdale, NJ: Erlbaum Associates.

Bloomfield, L. (1926/1957) A set of postulates for the science of language. Language 2, 15364. Reprinted in M. Joos (ed.), Readings in linguistics I. Chicago: University of Chicago Press, 1957.

Bollinger, D. (1969) Categories, features, attributes. Brno Studies in English, 8, 37-41.

Brown, R. (1986) Social psychology. New York: Free Press. $2^{\text {nd }}$ edition.

Brutt-Griffler, J. (2002) World English: a study of its development. Clevedon: Multilingual Matters.

Butler, Y. G. (2002) Second language learners' theories on use of English articles. Studies in Second Language Acquisition, 24, 451-480. 
Canagarajah, S. (2007) Lingua Franca English, multilingual communities and language acquisition. Modern Language Journal, 91, 923-939.

Carroll, J. B. (Ed.) (1956) Language, thought, and reality: selected writings of Benjamin Lee Whorf Cambridge, MA: MIT Press.

Chomsky, N. (1965) Aspects of the theory of syntax. Boston, Mass.: MIT Press.

Chomsky, N. (1972) Language and mind. Enlarged edition. New York, NY: Harcourt and Brace.

Chomsky, N. (1981) Lectures on Government and Binding. Dordrecht, Foris.

Chomsky, N. (1995) The Minimalist Program. Boston, Mass.: MIT Press New Horizons.

Chomsky, N. (2005) Three factors in language design. Linguistic Inquiry. 36, 1, $1-22$.

Cobbett, W. (1819) A grammar of the English language. Reprinted Oxford University Press 1984.

COBUILD dictionary (1995) Collins COBUILD English Dictionary. Harper Collins.

Common European framework of reference for languages (2001). Strasburg: Council of Europe, Cambridge University Press

Cook, V. J. (1981) Second language acquisition from an interactionist viewpoint. Interlanguage Studies Bulletin-Utrecht, 6, 93-111.

Cook, V. J. (2003) Introduction: the changing L1 in the L2 user's mind. In Cook, V.J. (ed.), Effects of the second language on the first. (pp.1-18) Clevedon: Multilingual Matters.

Cook, V. J. (2007) The nature of the L2 user. In L. Roberts, A. Gurel \& L. Marti (eds.) EUROSLA Yearbook, 7, 205-220. Reprinted in L. Wei (ed.), The Routledge applied linguistics reader (pp. 77-89) London: Routledge.

Cook, V. J. (2009) Multilingual Universal Grammar as the norm. In I. Leung (ed.), Third language acquisition and universal grammar. (pp. 55-70) Bristol: Multilingual Matters.

Cook, V. J. (2010) Prolegomena to second language learning. In P. Seedhouse \& S. Walsh (eds), Conceptualising language learning. (pp. 6-22) Basingstoke: Palgrave MacMillan.

Cook, V. J. (2011) Relating language and cognition: the speaker of one language. In Cook, V. J. \& Bassetti, B. (eds.) (2011) Language and bilingual cognition. (pp. 3-22) New York, NY: Psychology Press. 
Cook, V. J. \& Bassetti, B. (eds.) 2011. Language and bilingual cognition. New York, NY: Psychology Press.

Coventry, K., Guijaro-Fuentes, P. \& Valdes, B. (2011). Spatial language and second language acquisition research. In Cook, V. J. \& Bassetti, B. (eds.) (2011) Language and bilingual cognition. (pp. 315-340) New York, NY: Psychology Press.

Croft, W. (2010) Relativity, linguistic variation and language universals. Cognitextes, 5 http://cognitextes.revues.org/.

Cruse, D.A. (1986) Lexical semantics. Cambridge: Cambridge University Press.

Davidoff, J., Davies, I., \& Roberson, D. (1999) Color categories in a stone-age tribe. Nature, 398, 203-204.

Deese, J. (1966). The structure of associations in language and thought. Baltimore: John Hopkins Press.

De Groot, A. M. B. (2010). Bilingual cognition: an introduction. New York, NY: Psychology Press.

de Saussure, F. (1916/1976) Cours de linguistique générale. Bally, C. \& A. Sechehaye (eds.) 1915. Critical edition by T. de Maurio. Paris: Payothèque, Payot.

Dorais, L.-J. 1988. Tukilik: an Inuktitut grammar for all. Quebec, QC: Association Inuksiutiit Katimajiit. Cited in Genesee, F). (2003) Portrait of the bilingual child. In V. Cook (ed.), Portraits of the L2 user. (pp. 170-196) Bristol: Multilingual Matters.

Edinburgh Word Association Thesaurus (2011), http://www.eat.rl.ac.uk/.

Ekiert, M. (2010) The linguistic effects on thinking for writing: The case of articles in L2 English. In Han \& Cadierno. Linguistic Relativity in Second Language Acquisition: Thinking for speaking (pp. 125-153) Clevedon: Multilingual Matters.

Evans, N. \& Levinson, S. (2009) The myth of language universals: language diversity and its importance for cognitive science. Behavioral and Brain Sciences, 32, 429-448.

Evans, V. 2011. Language and cognition; the view from cognitive linguistics. Cook, V. J. \& Bassetti, B. (eds.) 2011. Language and bilingual cognition (pp. 69-108) New York, NY: Psychology Press.

Fauconnier, G. (2003) The way we think. New York: Basic Books

Firth, A. (2009) Doing not being a foreign language learner: English as a lingua franca in the workplace and (some) implications for SLA. International Review of Applied Linguistics, 47, 127-156

Fries, C. C. (1952). The structure of English. New York: Harcourt Brace. 
Genesee, F. (2003). Portrait of the bilingual child. In V. Cook (ed.), Portraits of the L2 user. (pp. 170-196) Bristol: Multilingual Matters.

Gentner, D. \& Goldin-Meadow, S. (Eds.) 2003. Language in mind: advances in the study of language and Thought. Cambridge, MA: The MIT Press.

Goldin-Meadow, S., So, W.-C., Ozyurek, A., \& Mylander, C. (2008) The natural order of events: How speakers of different languages represent events nonverbally. Proceedings of the National Academy of Sciences, 105, 9163-9168.

Greenbaum, S. (1996) Oxford English grammar. Oxford: Oxford University Press.

Grosjean, F. (1998). Transfer and language mode. Bilingualism: Language and Cognition, 1, 3, 175-176.

Hale, K. (1983) Warlipiri and the grammar of non-configurational languages. Natural Language and Linguistic Theory, 1, 5-47.

Halliday, M. A. K. (1978) Language as social semiotic. London: Edward Arnold.

Han, Z. \& Cadierno, T. (eds.) (2010) Linguistic relativity in SLA: thinking for speaking. Bristol: Multilingual Matters.

Humboldt, W. von (1836/1999) On language. Translated by P. Heath. Cambridge: Cambridge University Press.

Imai, M. \& Gentner, D. (1997) A cross-linguistic study of early word meaning: universal ontology and linguistic influence. Cognition, 62, 169-200.

Jarvis, S. \& Pavlenko, A. (2009) Crosslinguistic influence in language and cognition. Abingdon: Routledge.

Jelinek, E. (1995) Quantification in Straits Salish. In E. Bach, E. Jelinek, A. Kratzer \& B. Partee (eds.), Quantification in natural languages. (pp. 487-540) Kluwer.

Jespersen, O. (1933) Essentials of English grammar. London: Allen \& Unwin.

Laitin, D. D. (2000) What is a language community? American Journal of Political Science, 44, 1, 142-145.

Leech, G. \& Svartvik, J. (1975) A communicative grammar of English. London: Longman.

Levinson, S. (1996) Relativity in spatial conception and description. In J. J. Gumperz \& S. C. Levinson (eds.). Rethinking linguistic relativity. (pp. 177-202) Cambridge: Cambridge University Press.

Levinson, S. C. (2003) Language and mind: let's get the issue right. In Gentner and Goldin-Meadow (eds.), Language in mind. (pp. 25-46) Cambridge, Mass.: MIT Press.

Lewin, K.(1935) A dynamic theory of personality. New York, N.Y.: McGraw-Hill. 
Lewis, M. Paul (ed.) (2009) Ethnologue: languages of the world. Sixteenth edition. Dallas, Tex.: SIL International. Online version: http://www.ethnologue.com/.

Lucy, J. A. (1992) Grammatical categories and cognition: a case study of the linguistic relativity hypothesis. Cambridge: Cambridge University Press.

Lucy, J. A. (1997) Linguistic relativity. Annual Review of Anthropology, 26, 291-392.

Lyons, J. (1966) Towards a "notional" theory of the "parts of speech". Journal of Linguistics, 2, 2, 209-236.

Mackey, W. F. (1972) The description of bilingualism. In Fishman, J. A. (ed.), Readings in the sociology of language. (pp. 554-584) The Hague: Mouton.

Malinowski, B. (1923) The problem of meaning in primitive languages. In C. K. Ogden \& I. A. Richards, The meaning of meaning (pp. 296-336) London: Routledge Kegan Paul.

Malt, B. C. \& Ameel, E. (2011). The art and science of bilingual object naming. In Pavlenko (ed.) Thinking and speaking in two languages (pp. 170-197) Bristol: Multilingual Matters.

Master, P. (1994) The effect of systematic instruction on learning the English article system. In T. Odlin (Ed.), Perspectives on pedagogical grammar. (pp. 229-252) Cambridge: Cambridge University Press.

Oxford English Dictionary (1997) 2nd revised edition. Oxford: Oxford University Press. Online at http://www.oed.com/.

Pavlenko, A. (ed.) 2011. Thinking and speaking in two languages. Bristol: Multilingual Matters.

Quirk, R., Greenbaum, S., Leech, G. \& Svartvik, J. (1972) A grammar of contemporary English. London: Longman.

Regier, T. \& Kay, P. (2009) Language, thought and color: Whorf was half right. Trends in Cognitive Sciences, 13, 10, 439-446.

Robins, R. H. (1952) Noun and verb in universal grammar. Language, 28, 289-298.

Rosch, E. (1977) Human categorisation. In N. Warren (ed.), Advances in crosscultural psychology, 1 (pp. 1-72) London: Academic Press.

Sapir, E. (1921) Language: an introduction to the study of speech. Reprinted no date by: Harcourt Brace and Co, New York.

Schegloff, E. A., Koshik, I., Jacoby, S. \& Olsher, A. (2002) Conversation analysis and applied linguistics. Annual Review of Applied Linguistics, 22, 3-31.

Seidlhofer, B. (2004) Research perspectives on teaching English as a lingua franca. Annual Review of Applied Linguistics, 24, 209-239. 
Sera, M. D., Forbes, J., Burch, M. C. \& Rodriquez, W. (2002) When language affects cognition and when it does not: An analysis of grammatical gender and classification. Journal of Experimental Psychology: General, 131, 377-397.

Slobin, D.I. (2004) The many ways to search for a frog: linguistic typology and the expression of motion events. In Strömqvist, S. \& Verhoeven, L. (eds.), Relating events in narrative Vol 2, (pp. 219-257) Mahwah, N.J.: Lawrence Erlbaum.

Stringer, D. (2010) The gloss trap. In Han \& Cadierno (eds.) Linguistic Relativity in Second language Acquisition: Thinking for speaking. (pp. 102-124) Clevedon: Multilingual Matters.

Talmy, L. (1985) Lexicalization patterns: Semantic structure in lexical form. In T. Shopen (ed.), Language typology and lexical description: Vol. 3. Grammatical categories and the lexicon. (pp. 36-149) Cambridge: Cambridge University Press.

Talmy, L. (2005) The fundamental system of spatial schemas in language. In B. Hamp (ed.), From perception to meaning: image schemas in cognitive linguistics. (pp. 199243) Berlin and New York: Mouton de Gruyter.

Thomas, M. (1989) The acquisition of English articles by first- and secondlanguage learners. Applied Psycholinguistics, 10, 335-355.

Tomasello, M. (2003) Constructing a language. Cambridge, Mass.: Harvard University Press.

Tversky, B., Kugelmass, S. \& Winter, A. (1991) Cross-cultural and developmental trends in graphic productions. Cognitive Psychology, 23, 515-557.

Vygotsky, L. S. (1934/1962) Thought and language. Cambridge, Mass.: MIT Press.

Weinreich, U. (1953) Languages in contact. The Hague: Mouton.

Whorf, B. L. (1940/1956) Science and linguistics. Technology Review, 42, 8, 229-231, 247-248. Reprinted in Carroll (1956) Language, thought and reality: Selected writings by Benjamin Lee Whorf. Cambridge (pp. 207-219) MA: Technology Press of Massachusetts Institute of Technology.

Whorf, B. L. (1941a/1956) The relation of habitual thought and behavior to language. In L. Spier (ed.) Language, culture and personality. Reprinted in Carroll (1956) Language, thought and reality: Selected writings by Benjamin Lee Whorf. Cambridge (pp. 134-159) MA: Technology Press of Massachusetts Institute of Technology.

Whorf, B. L. (1941b/1956). Languages and logic. Reprinted in Carroll (1956) Language, thought and reality: Selected writings by Benjamin Lee Whorf. Cambridge (pp. 233-245) MA: Technology Press of Massachusetts Institute of Technology.

Wierzbicka, A. (1996) Semantics: primes and universals. Oxford: Oxford University Press. 
Wierzbicka, A. (2011) Bilingualism and cognition: the perspective from semantics. Cook, V. J. \& Bassetti, B. (eds.) 2011. Language and bilingual cognition. (pp. 191-218) New York, NY: Psychology Press.

Yeh, D. \& Gentner, D. (2005) Reasoning counterfactually in Chinese: picking up the pieces. Proceedings of the $27^{\text {th }}$ Meeting of the Cognitive Science Society, 2410-2415.

Zandvoort, R. W. (1957) A handbook of English grammar. London: Longman. 